\title{
Historical Modes of Perpetual Penal Confinement: Theories and Practices before Life Without Parole
}

\author{
Christopher Seeds
}

\begin{abstract}
Scholars now recognize life imprisonment without parole (LWOP) as a defining feature of contemporary American punishment. As LWOP becomes topical, it draws attention to a significant, more general phenomenon: the growth of state-sanctioned policies and practices by which prisoners face the remainder of their lives in prison. This article seeks to expand perspectives on contemporary punishment by looking closely at how lifetime incarceration took shape historically in different political projects and penal systems. Drawing from primary materials and a comprehensive review of secondary historical literature, I examine modes of perpetual penal confinement: combinations of sanctions and practices that result in holding people in state custody permanently. Interpreting classic penological paradigms anew, the article illuminates the significant role that perpetual confinement has played in influential theories of criminal justice and shows how it has proved a versatile tool for social control and prison administration across diverse penal schemes, largely because of its unique temporal character. The article concludes with a diagnosis of contemporary American punishment, suggesting that LWOP-beyond being a cruel and exclusionary penalty-is symptomatic of a system in which imprisonment until death has become uniquely ordinary.
\end{abstract}

\section{INTRODUCTION}

Over the last four decades life imprisonment without the possibility of parole, a prison sentence that provides no reasonable possibility of release, has become a common punishment for the most serious crimes in the United States, and even for not-so-serious crimes in some jurisdictions. The number of prisoners sentenced to life without parole has grown by tens of thousands (Nellis 2017), and more than 100 new state and federal laws have extended the sentence to a multitude of offenses and offender statuses (Seeds 2017). Other methods of imprisoning individuals until death have also increased: more prisoners serve long-term sentences that exceed their life expectancies (Schmitt and Konfrst 2015; Hamilton 2016; Nellis 2017; Henry, Salvatore, and Pugh 2018); and

Christopher Seeds is an Assistant Professor in the Department of Criminology, Law \& Society at the University of California, Irvine (cseeds@uci.edu). Thanks to the anonymous reviewers for valuable suggestions, and to David Garland, Gabriel Abend, Sarah Armstrong, Offer Egozy, Ashley Rubin, and Sox Sperry for especially helpful comments on earlier drafts. Versions of the article were presented at the Penal Boundaries Workshop at the Centre for Criminology and Sociolegal Studies at the University of Toronto in April 2016 and at the American Society of Criminology annual meeting in New Orleans in November 2016. This material is based upon work supported by the National Science Foundation under grant SES 1534640 for doctoral dissertation research and assisted by a Mellon-ACLS Dissertation Completion Fellowship from the American Council of Learned Societies. 
where administrative review boards deny parole with little regard for rehabilitation (Ghandnoosh 2017; Reitz 2018) or governors routinely veto parole grants (Simon 2007, 2012; Dolovich 2012; Zimring and Johnson 2012), prisoners are held perpetually despite being technically eligible for release (Kazemian and Travis 2015). Often dubbed "de facto life without parole" or "virtual life," these punishments are increasingly considered alongside formal life without parole (LWOP) sentences for purposes of policy analysis, litigation, jurisprudence, and scholarship (see Barkow 2012; Nellis 2017; Henry, Salvatore and Pugh 2018; Bell 2018). LWOP, as such, marks the head of a broader phenomenon: more prisoners serving sentences that outlast life-spans; a swell of laws and practices generating such sentences; and a social awareness, if not acceptance, of imprisonment until the end of life as a state-sanctioned punishment.

Yet prison sentences that outlast lifespans are nothing new. Minimum terms of twenty to twenty-five years have long been routine for first-degree murder in the United States. Natural life sentences have been authorized before for seemingly irreparable career criminals. Judges on occasion impose extremely long consecutive sentences even for nonhomicidal criminal conduct arising in a single incident. Parole and clemency, moreover, give the state a prerogative to deny release indefinitely to life-term prisoners deemed particularly dangerous. So the concept of treating certain offenders or offender groups as if they are infinitely excludable is not novel; nor is the practice of using the prison as a virtual death chamber. Over the first three-quarters of the twentieth century, such "ultimate penalties" (Sheleff 1987) were available in particular cases, and practices amounting to death in prison took place, even in jurisdictions with penal systems strongly oriented toward treatment and rehabilitation (Reitz 2012). LWOP presents one way in which individuals face the remainder of their natural lives in prison, but it is neither the first nor the only.

This article seeks to expand perspectives on contemporary punishment by looking to the history of life sentencing and other state-sanctioned practices under which prisoners faced the rest of their lives in prison. Drawing from primary materials (including laws, legislative histories, judicial opinions, and news media) and a comprehensive review of secondary sources concerning the history of penal policy and reform in the United States, I examine how lifetime punishments took shape and operated in five classic penological paradigms. I refer to these as modes of perpetual penal confinement: combinations of court sentences and penal practices that result in permanently holding people in state custody. From public penal servitude to experiments with imprisonment in the early United States and in the Progressive era, to habitual offender schemes and practices of convict leasing, each mode correlates with a critical juncture in the formation of American criminal justice.

In important and underappreciated ways, perpetual penal confinement has been fundamental to theories and practices of punishment. This article shows how, more than merely present in these political projects and penal schemes, perpetual confinement was integral, embodying the principles of each approach and at times acting as a hinge upon which the system of punishment depended. In the classical criminology of Cesare Beccaria, so influential in the colonies and early United States, perpetual public servitude was no curious anomaly; it exemplified the core deterrent principle of the scheme, serving an extraordinary but crucial ongoing symbolic function. For Pennsylvanian reformer Benjamin Rush, the vision of a remote house in which prisoners 
did not know their sentence and lacked reasoned hope for release underpinned his advocacy for the prison as a site of redemption and prelude to social reintegration. Progressive-era theorists such as Frederick Wines knew well that an indeterminate sentencing scheme (employing open-ended sentences dependent upon administrative review) had an unavoidable and essential underside in circumstances where rehabilitation failed-permanent incapacitation. And so on. In each case, the infinite temporal character of perpetual confinement offered a break from other punishments available in the system, contributing something exceptional that finite terms of imprisonment could not. Largely because of this unique time-based aspect, perpetual confinement has proved a versatile tool for social control and prison administration, offering different benefits in different systems, including those seeking humane punishment and even those prioritizing rehabilitation and reform. Perpetual confinement is always a severe and exclusionary punishment. Yet in classic theories and practices it often served as something more.

Approaching perpetual penal confinement as a discrete object of studyrecognizing it as a social form that can be assessed across contexts-does more than provide insight into the punishment's character. It offers a window for understanding penal systems and for clarifying the fundamental intents and beliefs that underlie them. State-sanctioned policies and practices by which prisoners spend the remainder of their lives in prison are not often considered to constitute a category from which different forms might be analyzed and compared across jurisdictions or over time (for exceptions, see Van Zyl Smit 2002; O'Donnell 2014; Van Zyl Smit and Appleton 2016, 2019). Yet the shapes and uses of perpetual confinement vary with prevailing political strategies, penal aims, and underlying assumptions about crime, punishment, criminals, and prisoners. Just as the death penalty takes on a different character in different penal systems (Garland 2010, 2011), as does the fine (Rusche and Kirchheimer [1939] 2003; Foucault [1972-1973] 2015, 8-9), so too does perpetual confinement. If one wants to understand the logic of a penal scheme, one might look at how that system utilizes imprisonment until death.

The following section summarizes my approach to investigating historical modes of perpetual confinement. Expositions of the modes, concentrating on the forms of perpetual confinement and how they relate to the penal schemes of which they are a part, make up the core of the article. I then discuss how this historical inquiry expands understanding and perspective on incarceration until death. The article concludes by considering how a historical knowledge of modes of perpetual confinement may tailor thinking about LWOP, the emergent form of perpetual confinement, in contemporary punishment in the United States.

\section{IDENTIFYING HISTORICAL MODES}

When a current practice or idea is a touchstone for historical inquiry, one must be careful not to impose an order of classification on the past that did not then exist (Skinner 1969). That risk, true for all punishments, is apparent when studying perpetual confinement. One cannot, for example, uncritically interpret a statute authorizing "life without parole" in the first decades of the twentieth century as having the same meaning as a statute that authorizes "life without parole" today. To manage this concern, I draw on perpetual confinement as I find it in systematic theories or commentaries 
on criminal justice reform. In these sources-the writings of late-eighteenth-century Italian reformer Cesare Beccaria, colonial Pennsylvanian reformer Benjamin Rush, Progressive-era theorist Frederick Wines, nineteenth-century Maryland legislator Daniel Raymond, and Southern author and social critic George Washington Cable-perpetual confinement is situated within a broader scheme, amid a set of underlying principles and "orienting ideas" (Schoenfeld 2014; see Abend 2014). In each, as summarized in Table 1, perpetual confinement is a product of its context, adopting certain forms and serving particular functions that reflect the principles, purposes, and underlying assumptions of the penal paradigms. I complement these sources with a comprehensive review of historical accounts of American punishment.

While this article presents the modes in a roughly chronological order, this is not intended as a history of how one mode transformed into another, for that did not

\section{TABLE 1.}

\section{Modes of Perpetual Penal Confinement}

The example In the systematic penal model of Italian reformer Cesare Beccaria, influential in the American colonies, prisoners were perceived as rational actors possessed with inherent dignity, whose treatment as a general matter should be proportionate to the offense. A primary purpose of punishment was to serve notice to the public. Public penal servitude-a perpetual term at hard labor-was available in cases of political expediency to serve as an enduring, visible deterrent.

The retreat In the penal theory of Benjamin Rush, introducing the prison to the early United States, incarceration related to a broader project of citizenship. The prison served the purpose of training fringe members for the social mainstream. Prisoners, each a potential citizen, were to serve terms of imprisonment at hard and often solitary labor of unknown duration, intended to induce reflection and social education through fear. Release was anticipated for most, but not all, through a faith-based trial to redemption.

The science of For Frederick Wines, whose views reflect the Progressive-era rehabilitative release model of corrections, the prisoner was a flawed citizen whose inherent dignity entitled them to an opportunity to demonstrate rehabilitation and gain release. Imprisonment gave criminals this chance. Perpetual imprisonment served as a necessary backstop-a holding space for prisoners who failed—and was justified only in that circumstance.

The dual track For nineteenth-century legislator Daniel Raymond, and the positivist criminology that followed, incapacitation itself was part of the democratic project. A separate track with separate prisons served to avoid contaminating welfarist penal facilities while safely quarantining certain categories of reviled or risky prisoners identified as incurable. Identifying certain prisoners as incurable provided a limited public health and safety justification for permanent incapacitation.

Penal slavery For the economically minded penal operators of the antebellum South, punishment was inextricably intertwined with race-based slavery. Prisoners' degraded status and loss of citizenship was used to justify the contractual penal labor (convict leasing, chain gangs, and penal farms) upon which the system financially relied. Prisoners' dignity was seen as sufficiently compromised to permit mortally threatening work conditions, regardless of a prisoner's sentence. 
necessarily occur. Nor is the goal to comprehensively document all instances and permutations of perpetual confinement in US penal history. Rather, my aim is to offer a deep look at how perpetual confinement fit in political and penal schemes. The modes are what Howard P. Becker called "undated and nonlocalized" (1940, 46; see also Rubin 2015, 2016 on the development and spread of penal ideas). They are contextually rooted, but they serve as examples of ways of thinking about and performing perpetual confinement that could apply in any place and at any time. The focus is on the forms and functions of perpetual confinement in these classic paradigms.

The study is not restricted to strategies that expressly intend to confine prisoners for the remainder of their lives. I include situations in which perpetual confinement, if not precisely the aimed-for outcome, could be anticipated as a consequence of postsentencing practices. For example, Progressive-era penal reform revolutionized US prison administration from the late nineteenth century onward (Garland 2001). Under the Progressive approach, the primary aim of imprisonment was to treat and rehabilitate-all prisoners had a chance for release. Even so, reformers expected, some prisoners would fail that chance and stay in prison forever (Reitz 2012). Consequently, perpetual penal confinement, while not the primary objective of Progressive-era reformers, was contemplated as a necessity (Wines 1895).

Another mode comprises the convict lease system, active in the American South in the late nineteenth and early twentieth centuries. In this system, death during confinement was a regular byproduct of incarceration-however long the court-imposed sentence-due to the brutal severity of forced labor conditions. Death under these circumstances, while not officially authorized, was so foreseeable that commentators such as George Washington Cable recognized it as a core component of the convict-leasing scheme (Cable 1889; accord Bentham 1843, 82, 85, defining "the magnitude of the punishment" to include both "intensity and duration"). Again, confinement for natural life was not necessarily an express sanction. Yet imprisonment until death was reasonably foreseeable.

What follows is principally an account of the intellectual origins of perpetual confinement, mapped in part through the efforts of penal reformers to translate their ideas into reality and in part through commentators' contemporaneous observations of existing penal practices. The further one goes back in time, the more it becomes necessary to focus on theories as a matter of evidence. Yet reform narratives developed in conversation with a public, they were meant for presentation to others and intended to persuade, and they were undoubtedly revised in light of expected and actual feedback (Hirsch 1992, 115; see Garland 1985, 74, 260; Garland 1990, 12; Smith 2008, 179-80). As Charles Bright said with respect to the prison, the relation between punishment and society requires a conversation and a justification that "fits" (1996, 293-94).

\section{MODES OF PERPETUAL PENAL CONFINEMENT}

\section{Mode 1: The Example}

Beccaria's On Crimes and Punishments ([1764] 2008), the classic Enlightenment statement of penal reform, was widely influential in the United States during the 
founding period (Bessler 2009, 206-15). The treatise accords penal servitude in perpetuity an important and somewhat perplexing role. In attacking the arbitrary infliction of disproportionately severe punishments, the tract replaces capital punishment with a sanction that is arguably crueler. Many judge this a glaring inconsistency. The amplified cruelty Beccaria selects in choosing perpetual penal servitude over the death penalty, however, is no anomaly. Instead, it is fundamental to the utilitarian-humanitarian fusion that characterizes his systemic thought on crime and punishment. As an endlessly repeated public demonstration, perpetual servitude serves as a lasting symbol of the rule of law that Beccaria finds so central to political legitimacy. As the preeminent deterrent, the punishment is no exception to Beccaria's scheme-rather, it is its centerpiece.

\section{Perpetual Servitude in Dei Delitti e Delle Pene}

Beccaria, a political economist, was concerned with optimal regulation of the state and the monarch's peaceful and productive rule. Influenced by Enlightenment principles of economic regulation, he valued utility. A benevolent state would promote the greatest happiness of its constituents by ensuring public safety and "bon marché" (Harcourt 2011, 73-76). Critical of loose arrangements in which criminal justice procedures and outcomes were directed by the discretion of prosecutors and judges, and in which corporal punishment, torture, and death were unnecessarily prevalent, Beccaria transposed a "police" model for regulating commerce onto the prevention and punishment of everyday crime. He proposed a comprehensive, well-publicized penal code under which punishment would be swift, certain, and proportionate to the crime. In this scheme, the law does what the law says, does so quickly, and does no more (Bierne 1993).

Beccaria also followed a humanist principle aligned with social contract theory, by which all individuals, including prisoners, are deemed worthy of respect and enjoy certain inalienable rights. In Beccaria's work, as in classical criminology generally, the assumption that all individuals are rational self-interested actors, who weigh costs and benefits in context, extends to the premise that all individuals are also potential criminals (given proper situational provocation) (Garland 2002, 11-12). As such, the public is susceptible to deterrence, and criminals can be utilized effectively as public examples. Following this logic, Beccaria advocated "moderate and prolonged punishments" that remained visible over time, instead of flaming out in a single dramatic spectacle. Lasting public punishment, in his words, provokes the "often repeated reflection that I myself shall be reduced to such a protracted and miserable condition if I commit similar misdeeds" (Beccaria [1764] 2008, 53). Put another way, "It is not the intensity of the punishment that has the greatest effect on the human mind, but its extension" (52). ${ }^{1}$ Deterrence then was produced in two ways: by public notice and by public punishment available for routine observation.

Along these lines, Beccaria argued for replacing the death penalty with perpetual public penal servitude. His objection to capital punishment was not simply that it

1. This passage from Beccaria is also translated as "It is not the intenseness of the pain that has the greatest effect on the mind, but its continuance" (see Beccaria [1764] 1963). 
exceeded the state's prerogative under the social contract or that it was graphically cruel. Instead, his main protest against the death penalty was that it was relatively ineffective as a general deterrent ([1764] 2008, 55). As he echoed years later: "The strongest impediment to crime is not the terrible and fleeting spectacle of the death of a wretch, but the long and repeated example of a man deprived of his liberty who with his labor is paying back the society he offended ... . One sole crime provides many and lasting examples" (Beccaria [1792] 2008, 156).

\section{Paradox and the Punitive City}

At a glance, Beccaria's concern with proportionality, his general opposition to the death penalty and unnecessarily violent punishments, and his general respect for human dignity sit uneasily — even incomprehensibly — with the grave cruelty of penal servitude in perpetuity (Newman and Marongiu 2009, xl-xli). As Dirk van Zyl Smit put it, there appears to be "some tension between Beccaria's overall penal theories on strictly proportional punishments and his support for life imprisonment" $(2002,7)$. This apparent ambivalence leads some to conclude that "Beccaria has no clear and uniform theory of punishment" (Bedau 1983, 1036), or that when it comes to ultimate penalties his theory holds a "paradox" (Bedau 1989, 485; see Sellin 1977). Beccaria provided little specificity about the practice of perpetual servitude (see McLennan 2008, 25), but clearly was aware of its harshness: "I shall be told that perpetual slavery is as painful a punishment as death, and therefore as cruel. I answer, that if all the miserable moments in the life of a slave were collected into one point, it would be a more cruel punishment than any other; but these are scattered through his whole life, whilst the pain of death exerts all its force in a moment" (Beccaria [1764] 2008). The piece on penal slavery, in short, may not fit with the rest.

A close look at Beccaria's system, however, shows that the use of penal servitude is not so puzzling as it initially may seem. Foucault (1977, 106, 129-30) characterizes Beccaria's scheme as "the punitive city," because punishment there, comprised of signs and obstacles disseminated in widespread and enduring publicity-a diffused power oriented more toward the public than the criminal-is a conversation with society. The scheme relied for crime prevention on an element of visibility completely different from the spectacle of the scaffold, which demonstrated and reinforced state power through fear by physically eliminating troublesome lawbreakers (Garland 2011). By Beccaria's estimation, perpetual servitude was no less harrowing, but far more enduring. It spread the staged "tragedy" (Garland 2011, 48 (quoting Bentham)) from a single moment across an infinite duration, taking it from a single platform and dispersing it through space. Perpetual public servitude shared an element of visibility with execution (compare Garland 2011, 39), but the function was altogether different. In a system that aimed to prevent crime through publicity, certainty, and repetition, the perpetual public ordeal possessed value as an enduring warning and constant reminder. Jeremy Bentham wrote something similar, arguing that a disproportionate punishment could be justified if it was "particularly well calculated to answer the purpose of a moral lesson" (Bentham $1843,89)$. It is this, Bentham continued, "that must justify the application of so severe a punishment as the infamy of a public exhibition" (89). 
It has also been said that the penal servitude passage is a moment where Beccaria, despite his humanism, gets "carried away with the thought of deterrence" (Young 1983, 321). Yet rather than an excessive slip, perpetual servitude is better seen as the key to the punitive city - the conceptual anchor of a scheme in which punishment's primary function, directed more to the public than to the prisoner, was ultimately to prevent and deter. The dignity of a particular individual and evenhanded application of law gave way in particular cases to the public good served by making an example. Punishment excessive and disproportionate for a particular case could be justified, despite its cruelty, by its utility in providing a visible and repeated illustration.

\section{Mode 2: The Retreat}

Beccaria's influence in the United States is seen clearly in Pennsylvania's criminal law reforms of 1786 . The new laws curtailed capital punishment and authorized the public punishment of wrongdoers, who were chained to wheelbarrows and forced to labor in clothes that plainly identified them as prisoners (Meranze 1996, 32-33). As Michael Meranze emphasizes, the wheelbarrow law, aiming to deter through public example, "embrace[d] Beccaria's dream of punishment as a well-ordered system of signs" (1996, 78, 82-84; see McLennan 2008). The wheelbarrow law was a short-lived experiment, however, that prompted great criticism, and four years later another round of reforms, in concert with efforts elsewhere in the United States, abolished public punishments and embraced the prison as the primary technology for punishing crime (Hirsch 1992, 115; Rothman 1995, 103).

The systematic thinking that laid the groundwork for the 1790 Pennsylvania reforms - opposing public punishments and marking the start of a Pennsylvania system of incarceration-is largely attributed to physician and reformer Benjamin Rush (Teeters 1955, 30-31, 39; Meranze 1996, 105-11). Like Beccaria, Rush's views on punishment were linked to his views on government and were forged in conversation with political activity. Yet the political context, the penal apparatus at hand, and his perspective on lawbreakers-indeed, the entire logic undergirding Rush's reform schemecould hardly have been more different. Rush's innovations were, in effect, a response to Beccaria (Rush 1787). Advocating for the prison as a technology of social control was, in part, a practical necessity given the social and political environment of early democracy (with increasing population and urban density, expanding property rights, industrialization, and a newly developing and growing polity). Rush, however, saw democracy as a process of education and retraining, in which the prison, no less than a school, was a privileged site for "transform[ing] the habits and mentalities of the citizenry" (Meranze 1988, v-vi). Every prisoner was a potential citizen whose dignity rested in the capacity for penitence and redemption.

\section{Imprisonment as the Unknown}

When Rush looked to the prison as a way to think about punishment, he drew on Pennsylvania roots and Quaker underpinnings. Rush's thought stems from a Quaker 
tradition averse to violence and, by extension, averse to corporal and capital punishment. Hence the Quaker preference for imprisonment that dates well into the early eighteenth century (Fitzroy 1936, 244-45; Barnes [1927] 1968, 35). Imprisonment had a natural affinity, in particular, with the Quaker tradition of the retreat. A necessary step toward salvation, the retreat consists of three key elements: removal from the social environment in which bad habits develop; a place of solitude, silence, and secrecy in which to contemplate change; and indefinite, even threateningly infinite, time.

These three qualities — removal, isolation, and indefinite time-surface as principles in Rush's model for the prison and stand in emphatic contrast to Beccaria's ideas (as well as those of Dufriche de Valaze, with which Rush expressly contrasted his proposal). First, Rush valued the prison as a deterrent, but not because of its public presence. Removal from society to places distant and spaces unknown was a useful source of fear. "[T] he human mind is disposed to exaggerate every thing that is removed at a distance from it," Rush wrote, "by time or place" $(1787,9)$. The overlap with banishment was not lost on Rush, as though banishment could be accomplished internally. Second, Rush sought to invoke fear through the unknown in prisoners and public alike, achieving reformation as well as general deterrence (Rush 1787, 10): "Let the various kinds of punishment that are to be inflicted on crimes be defined and fixed by law. But let no notice be taken in the law of the punishment that awaits any particular crime. By these means we shall prevent the mind from accustoming itself to the view of these punishments so as to destroy their terror by habit." Third, the duration of punishment would also be unknown to the prisoner: "I conceive this secret to be of the utmost importance in reforming criminals and preventing crimes. The imagination when agitated with uncertainty will seldom fail of connecting the longest duration of punishment with the smallest crime" (Rush 1787, 10). Whereas for Beccaria, the temporal value of a perpetual sentence was repetition, for Rush it was indefiniteness. Rush expected that most prisoners would translate uncertain durations of imprisonment as the longest sentence imaginable (Rush 1787). If Beccaria's vision is the "punitive city," Rush's is a dark cave, potentially a tomb.

\section{The Receptacle}

Rush referred to this prison site of indefinite confinement interchangeably as "the house," remote and horrifying, or "the receptacle" (1787, 9-10, 11):

Let a large house, of a construction agreeable to its design, be erected in a remote part of the state. Let the avenue to this house be rendered difficult and gloomy by mountains and morasses. Let its doors be of iron; and let the grating occasioned by opening and shutting them be increased by an echo from a neighboring mountain that shall extend and continue a found that shall deeply pierce the soul ... . To increase the horror of this abode of discipline and misery, let it be called by some name that shall import its design ... . If the receptacle for criminals which has been proposed is erected in a remote part of the state, it will act with the same force upon the feelings of the human ears as perpetual banishment. 
Three conditions regulated the severity of conditions in the receptacle-labor, light, and companionship-each a gift denied to the most culpable (Rush 1792, 14). Solitary confinement without labor was a defining feature of this "Pennsylvania method." Physical conditions were dire, and the intentional opacity of the scheme imposed a heavy psychological burden on prisoners. Accounts of life in Pennsylvania prisons describe it as a soul death, where any reasoned thought of release might actually be impossible (Tallack 1889, 155; see Dayan 2011, 70 (following John Locke)).

Belief in release, however, was not absent. Quakers trust that God leaves no one behind. The criminal, too, less a rational actor than a frail and morally deficient individual, was in effect a sinner who could be saved (Rothman 1971, 78; Foucault [1972-1973] $2015,88)$. Rush expected humanity to overcome brutal solitary conditions through physical and spiritual labor. The threat of limitless time in the receptacle was ideally suited for inducing internal reflection and reeducation: lurking in every sentence, the possibility of perpetual imprisonment functioned as an omnipresent tool for reform. Prisoners' dignity as such was linked to an austere faith to be found in the experience of imprisonment. All prison sentences in Rush's scheme were to be experienced as perpetual. And for those who failed, actual natural life imprisonment stood at the margins: "In confinement he may be reformed, and if this should prove impracticable, he may be retained for a term of years, that will probably be coeval with his life" (Rush 1787, 32). Perpetual confinement was the nature, if not the ultimate intent or actuality, of the retreat.

Rush's vision of a house shut off from the world, invoking fear inside and out, motivated a number of penal projects (Eastern State Penitentiary in Pennsylvania and Sing Sing Prison in New York are excellent examples (Lewis 1965, 140)), and the practice of solitary confinement with labor took hold; but Rush's dream of opaque sentences for all prisoners did not. More often, rather than impose sentences of unknown duration, judges fixed sentence lengths (Fitzroy 1936, 247). Given limited resources, life sentences were rare, used for only the most serious crimes and repeat offenders (Fitzroy 1936, 239).

\section{Mode 3: The Science of Release}

By the second half of the nineteenth century, the prison was nationally engrained as an institution, yet deemed a failure. Skepticism toward the prison and related procedures, such as fixed sentencing and executive clemency, had brewed to a crisis point. So when a renewed political movement toward democracy arose in the last quarter of the nineteenth century, it looked to a new technology: parole, a program for prison release. As William Tallack $(1896,9)$ said, emphasizing the prison's declining repute: "The main object of every prison is to be empty." This marks an early stage of what is referred to as "penal welfare" (Garland 1985) or the "rehabilitative ideal" (Allen 1981), an approach to imprisonment focused on treatment with an eye to release (see generally Cullen and Gilbert 2013).

\section{Science over Sunbeams}

The Transactions of the National Congress on the Penitentiary in Cincinnati in 1870 constituted, in effect, an inquisition on prior decades of penal policy. At this 
meeting, two principal criticisms were lodged: one of sentence duration, the other of pardon. To both, the life sentence was integral.

By the time of the Cincinnati Congress it was clear that duration of imprisonment presented one of the great puzzles of criminal justice (Wines 1870, 95). In the United States, fixed sentences set by a court, which prisoners had to serve in full, were prevalent. Reformers urged that fixed sentences tended to both overpunish or underpunish: because judges and legislatures could not know at the outset precisely when a prisoner would be safe to release, a prisoner might be released before "cured," or "cured" but still detained (Wines 1870). In effect, with fixed sentencing the law attempted the impossible: "Justice is an abstraction, elusive as a sunbeam ... A criminal court is a trap to catch sunbeams. Neither the legislature nor the court can make use of a non-existing pair of scales with imaginary weights ... . How long a time is uncertain and cannot ever be foretold in advance" (Wines 1904, 11; see Wines 1885, 13, 17). Further, courts in different jurisdictions and even judges in the same jurisdiction applied fixed sentences differently for similar crimes, undercutting the equity and certainty of the law (Wines 1885, 8; Wines 1895, 213). Clemency practices compounded these problems. On the one hand, clemency was a useful if not necessary mechanism for regulating the prison population as it alleviated overcrowding and managed prisoner morale. On the other hand, clemency was also a source of arbitrariness and graft. As New York reformer Thomas Eddy stated decades earlier, the "[b]itter and inescapable reality [of overcrowding] ... made virtually indiscriminate pardoning a necessity," yet it was an "unwelcome remedy" (Lewis 1965, 42).

Critiques of fixed sentences and clemency converged in the application of life sentences. With executive clemency as a release mechanism, life-sentenced prisoners might serve shorter terms than fixed-time prisoners for similar offenses. For example, in Ohio between 1857 and 1867, the average time served by life-sentenced prisoners was six years, seven months, and five days; in Wisconsin, it was six years (Wines and Dwight 1867, 298). In either case, the time served on a life sentence was shorter than a fixed term of seven or more years. Fixed sentences and clemency thus combined in failure. The indeterminate sentence-under which release decisions were made during the prison term, not before; for which release was based on prison conduct, not mercy; and in which decisions were made by expert administrators, not politicians and elected officials (Wines 1904, 11)—was offered as the solution to both problems.

\section{The Indeterminate Sentence: Two Views}

To fully consider the form and function of the life sentence in the context of indeterminate sentencing, it is useful to contrast the different views of Frederick Wines and Zebulon Brockway. Frederick Wines was not the only Progressive thinker for whom the prison was a locus of social reform. In fact, his views were rather common among, and in many ways representative of, prison reformers in the United States and abroad, including his father, Enoch Wines, Alexander Maconochie in Australia, Walter Crofton in Ireland, and the Hill brothers in the United Kingdom.

Although all these figures overshadow Frederick Wines in the textbook history of the indeterminate sentence and parole, two qualities make Wines exceptional for a 
study of life sentencing. First, more than other players in the indeterminate sentencing movement, who were prison wardens or superintendents of prison systems, Wines, who was not a practitioner, developed his views as a full system for understanding crime, criminals, and the causes and prevention of crime, as well as punishments, prison administration, and government. Wines's work was arguably the "prison system devised by the philosopher," which Elmira warden Zebulon Brockway distinguished from his own blueprint "drawn from experience" (see Wines 1870, 38). Yet Wines was not writing from a remote pedestal; he was actively in conversation with reformers and politicians, in work meant to publicly persuade.

Second, no penologist may ever have spent greater effort to theorize or collect empirical data on life sentencing than Frederick Wines. For Wines, the life sentence was the crux of rehabilitation. If not for the inherent human frailties of prison administrators, officers, and others positioned to make determinations about reform and release, Wines saw no need for any carceral sanction other than a life sentence (Wines 1885, 22; Wines 1895, 33). So while Frederick Wines's views on punishment generally represent progressive reform strategies, his work is unique in that he (i) theorizes indeterminate sentencing in a system and (ii) theorizes the life sentence as the indeterminate sanction par excellence.

One of the most important aspects of Wines's thought on life sentencing can be gleaned by distinguishing his view from Zebulon Brockway's. Brockway's model, first practiced at Elmira prison in New York in the 1870s and practiced in every state by the 1930s, set both a minimum prison term after which parole was possible and a maximum term at which release was mandatory (Wines 1870, 54). Based on decades of efforts to use something other than time as a measure of sentence, the method operated on work merits, which served as a basis for time credits and parole. Insofar as Brockway's model adjusted sentences that had been imposed by judicial discretion or legislative mandate, it was something of a compromise. Wines's perspective was slightly different. Referring to Brockway's approach as "conditional liberation," Wines reserved the term "indeterminate sentence" for a sanction with no minimum or maximum limit (Wines 1885, 3). For Wines, an indeterminate sentence was in all cases a life sentence under which a prisoner possessed an opportunity for release as soon as they proved rehabilitated, but no sooner. This was precisely the opposite of a time sentence, not merely a time sentence with an early release option (Barnes and Teeters 1952, 21). In Wines's ideal, clock and calendar were removed altogether.

\section{The Chance}

Many nineteenth-century reformers viewed rehabilitation as the result of a conscious, goal-driven process of work (see Wines 1885, 3-5). Prisoners knew their sentence; they knew of an opportunity for release; they knew that certain "experts" would make this determination according to ostensibly objective measures. Prisoners were shown an opportunity for release and were incentivized to earn it. This view of release as a product of labor is what Progressive reformers expected would justify what were otherwise objectionably long prison sentences (Wines and Dwight 1867, 276). The relationship between labor and rehabilitation was linked, in turn, to how reformers 
viewed prisoners' hopes for release: work was a foundation for reasonable hope. Frederick Wines captures this in the notion of a prisoner's "chance" $(1904,16)$ : "What the new criminology stands for is, in the first instance, discrimination between wrongdoers, and patient tolerance, under surveillance .... It cherishes no illusive expectation that the methods employed will accomplish the impossible: that all prisoners will yield to them .... But it insists that the convict is entitled to his chance-a chance which possibly he never before had."

The opportunity to work toward rehabilitation, a privilege due all prisoners, however, could be wasted and lost. As Frederick Wines stated, the "strength of the indeterminate sentence" was "its positive power to accomplish two distinct and desirable ends": "to reform criminals who are susceptible of reformation and to relieve society perpetually of the presence of such as are irreclaimable" $(1885,10)$. Even William Tallack, who criticized perpetual confinement as a slow death penalty, found it proper in "abnormal cases" for "intractable being[s]": "creature[s] with the speech and form of humanity but with ... the malevolent passions of a demon" (1889, 180-81). As a London paper, The Spectator, put it, indeterminate sentencing was sure to work, "monsters and accidents excepted" (Wines and Dwight 1867, 277). Contemporary scholars have shown that the turn to a rehabilitative paradigm was not necessarily something states did absolutely or not at all (Lynch 2010; Schoenfeld 2014). Wines's thought on life sentencing reminds us that, even in states that turned more fully to rehabilitation as a penal aim, treatment and incapacitation were flip sides of the same coin. ${ }^{2}$

\section{Mode 4: The Dual Track}

In the last decades of the nineteenth century, release practices corresponded with the rising power in criminal justice of scientific analysis and expertise. Emerging sciences including psychiatry, psychoanalysis, and criminology influenced penal theories and practices, with identifiably different effects at different levels of the criminal justice apparatus. On the one hand, the emerging sciences claimed to have a capacity to diagnose individual frailties that supported the prison's new role as a site of individualized treatment. At the institutional level, the treatment revolution echoed Rush's view of imprisonment as an open-ended process, but (as discussed above) with an end point determined by science rather than religion, by experts rather than governors, and in which rehabilitation was evinced externally, not internally. On the other hand, elements of criminology, eugenics, and psychiatry were bent on distinguishing the unique characteristics of criminal, dangerous, or inferior types. Positivist criminology, represented by the work of Cesare Lombroso, transformed the meaning of criminal offending. At the level of lawmaking, criminological and eugenics-based research supported

2. Kevin Reitz $(2012,277)$ has put it this way: "There has always been a puzzle about the true personality of the process .... As a means of setting prison terms, the rehabilitative premise is unavoidably paired with a less compassionate incapacitative program .... From its origins, there has been a deep tension in underlying policies, and the potential for 'soft' and 'hard' treatment, within the indeterminate framework." 
explicit measures for preidentified individuals and groups deemed to be unfit for the rehabilitative project, apparently immune to reform. ${ }^{3}$

\section{The Perpetual Workhouse}

Daniel Raymond's mid-nineteenth-century vision of a "perpetual workhouse" presages the scientific approach that became influential at the century's end. Raymond - a Maryland congressman, political economist, and prominent antislavery activist - offered the perpetual workhouse as part of a systematic plan for reform that he prepared in response to a national survey on the penitentiary (Raymond 1822). Raymond was admittedly not a penal expert, but his proposal reflected long-standing institutional and public concerns about the prison. In particular, holding serious criminals in a standard institution risked irreparably influencing or "prisonizing" the less serious offenders present (Clemmer 1940; see de Beaumont and de Toqueville 1833). On occasion, reformers prescribed separate penal facilities to safely quarantine incurable prisoners and avoid contaminating welfarist penal facilities. Such "dual track" ${ }^{4}$ schemes were a minority, but not altogether uncommon in the nineteenth century (see Allen, Hopkins, and Tibbets 1825, 125, advocating a perpetual "criminal colony" for those labeled incorrigible). Raymond's perpetual workhouse was among the first.

Raymond's proposal was largely a reaction to the Pennsylvania model, shaped by the manner in which the Pennsylvania model conflicted with Raymond's own assumptions about human nature. The character of the human spirit, per Raymond, was to accommodate hardship and persist. Raymond believed, therefore, that most individuals would not experience imprisonment as punishment for long (1822, A41): "[I]f a man is sentenced to the Penitentiary for ten years, and after remaining there three months, becomes so accustomed to it as to enjoy an ordinary share of happiness, confinement for the remaining nine years and nine months is in reality without any effect whatever ... and a mere mockery of punishment." He similarly questioned the wisdom of allowing prisoners to work, which he saw as a cure for the human spirit, not a punishment. As Raymond believed it should be a "principal object to extinguish every ray of hope of escape in the mind of the accused criminal and of the convicted felon" (1822, A51-52), prisons and workhouses as such were irreconcilable. "I cannot myself well imagine a greater absurdity," he wrote, "than to think to punish a man by compelling him to labor" (1822, A42-43). Raymond nevertheless recognized that habits, once obtained, are hard to break. To ensure against prison habits, Raymond recommended imprisonment for no more than "six months and in most cases not near so long" (1822, A48).

For each of these reasons, Raymond considered long-term imprisonment incompatible with punishment or reform. For imprisonment to be effective, he believed, it must operate for short durations under dire conditions. And yet, if a "first grade" of criminals could be dealt with by corporal punishment, and a "second grade" redeemed

3. For a detailed, comparative historical account of how positivist criminology influenced penal policy in the United States and Europe, see Pifferi (2016).

4. The term "dual track" is adopted from a well-known, but ultimately little used approach to managing habitual offenders in early-twentieth-century England and Wales (Radzinowicz and Hood 1980). 
by solitude and deprivation, there was a "third grade" - the most serious and repeat offenders-for which short terms would not suffice (1822, A48-49):

For the third grade of criminals, I would provide a perpetual workhouse, somewhat upon the plan of our present penitentiaries. I call it a perpetual workhouse because I would have none sentenced to it but for life. It is designed for incorrigible offenders, for whose reformation there is no hope, and whose characters render it dangerous to suffer them ever to be let loose again upon society. I would set them to work to prevent them from being a burden to the state, and as they are never again to be let loose upon society, it is of little importance what habits they form, nor can there be any objection to their enjoying as much happiness as is consistent with their safety. There can be no object in punishing them with idleness and solitude.

Into this perpetual workhouse, I would in the first place put all those incorrigible offenders who had repeated their crimes after having been at the whipping post or in the penitentiary. I would also put into it persons guilty of murder in the second degree ... also, those guilty of arson, of rape, of man-stealing, of highway robbery, of perjury, and perhaps counterfeiters for the first offense. Indeed, all persons who have evinced that incorrigible depravity of heart, which renders them dangerous to society should be sentenced to this perpetual workhouse. To it I would sentence none but for life; since to confine them there for a term of years and then turn them upon society is to make them felons by a regular course of discipline.

The contrast between Raymond's proposed island colony and the mainstream prison highlights how different the character of confinement may be once individuals are simply written off. In contrast to Benjamin Rush, who proposed harsh conditions as a step to reform-and to Rush's vision of the receptacle, in which prisoners were only to believe their sentences perpetual-for Raymond separation (not deprivation) was the primary objective. Rather than working their way out of prison, these preidentified failures worked simply to keep the institution afloat. In this detached place, the passing of time did not matter, nor did institutional knowledge of what transpired.

\section{Sequestering Social Enemies}

The perpetual workhouse foreshadows a new perspective on criminals that undergirded twentieth-century habitual-offender and sex-offender laws and practices in the United States. Natural life sentences for repeat felonies existed in codes from colonial times. Most were holdovers from old English or Quaker provisions in which "life" was routinely the sanction for second, third, or fourth commissions of the same offense (see Virginia Law Review 1962, 598-99). Individuals were rarely prosecuted under such laws, and life sentences rarely carried out, in part because states simply lacked facilities to hold prisoners for long periods.

As emerging sciences converged on the criminal law, however, the notion of repeat offending changed. As Foucault among others notes, where there once was "the 
offense and the penalty," by the late nineteenth century there was also the "criminal": a dangerous type whom criminology professed to understand and psychiatry vowed to reveal (Foucault 1978). The repeat offender transformed from a person who committed the same offense multiple times (the recidivist) to a criminal type (the habitual offender), who was predisposed to crime and posed a public safety concern (Lombroso [1896] 2006; Morris 1951, 1967; see Kramer 1982). A similar conceptual transformation occurred with sex crimes. Where there once were sex offenses now entered sex offenders-a biological type of "degenerates, homicidal sex fiends, and perverts" (Jenkins 2004, 26-28), suffering from maladies with vague and only ostensibly discoverable cures (Hacker and Frym 1955).

These conceptualizations of social enemies, who posed risks to public health as much as public safety (see Swanson 1960; Lynch 2002), resonated with social Darwinism, eugenics, and other positivist or biosocial theories. And as the prison was redefined as a place of treatment and rehabilitation, these predetermined criminal types were juxtaposed and rerouted to detention centers (Timashefe 1939). Over the twentieth century, habitual-offender laws and sex-offender laws developed in waves, often responding to moral panics spurred by specific crimes and crystallized by entrepreneurs who shaped public concerns (McCuaig 1929; Sutherland 1949; see Leon 2011). As with Raymond's island, these laws were in a sense more symbolic than real: harsh on paper, but rarely used and often nullified in practice (Tappan 1949; Janus and Prentky 2008).

\section{Mode 5: Penal Slavery}

Penal slavery presents a circumstance in which there is a reasonable expectation that a prisoner will live out the remainder of life in confinement, but, in contrast to the preceding four modes, this is not necessarily a consequence of decisions made by penal state actors about sentencing and release. Rather, in this situation perpetual confinement is determined by (i) a status denigration applied to prisoners, which (ii) enables penal labor under mortally severe conditions.

One finds early roots of slavery as punishment in the Roman Empire. Citizens of the Republic convicted of crimes were stripped of their civic responsibilities and entitlements, and sentenced and rebranded as slaves at hard labor for the rest of their lives (Sellin 1976). Centuries later in continental Europe, long terms at hard labor under conditions so severe that death was likely took the form of galley slavery in the bagnes (a stationary contract-labor site at navy yards under state control) and of imprisonment at labor with irons (Howard 1789; Langbein 1976). As in Rome, a loss of civil rights was part and parcel of the punishment (Sellin 1976, 49): "According to law ... not only execution but a life sentence to the galleys was also a capital punishment ... . Such punishments automatically resulted in the confiscation or loss of the offender's property and in his civil death, which in fact meant that he took on the attributes of a chattel slave, a nonperson in the eyes of the law."

This pairing of status degradation with life-threatening labor finds an early American analog in the legal rubric of civil death. Civil death, first found in state codes of the late eighteenth century, removed convicts' legal rights (Lewis 1965; McLennan 2008, 2011), 
from property rights to the right to vindicate other rights in court (such as challenging prison conditions). As Rebecca McLennan (2011) and Colin Dayan (2011) illustrate, civil death amounted to losing legal personhood. Civil-death laws left the prisoner something of a half-person, with a "double status as a human and regulated object" (Dayan 2011, 203). This eroded status enabled contractual penal labor practices_often mortally threatening - that otherwise would have been legally untenable. When the Thirteenth Amendment abolished slavery, an exception allowed slave labor for prisoners (see, for example, Lichtenstein 1996; McLennan 2008). The Thirteenth Amendment, as such, provides a "discursive link" (Dayan 2011, 64) between slavery and civil death.

\section{Convict Leasing in the Silent South}

Penal servitude in American punishment was both a Northern and a Southern phenomenon. Civil-death laws first paired with contractual labor practices in Northern prisons, then spread South (McLennan 2008; see Lewis 1965). For economically minded penal operators of the North and South, labor-based operations were selfsustaining enterprises in which financial gain was as important as crime control. In the post-Civil-War South, however, given the poverty of the Southern states and the lack in most of a centralized bureaucracy (Taylor 1993; Oshinsky 1996; Schoenfeld 2014), penal servitude took place at "outposts" rather than prisons (Mancini 1996, 1): "For half a century following the Civil War, the Southern states had no prisons to speak of, and those they did have played a peripheral role in those states' criminal justice systems. Instead, persons convicted of criminal offenses were sent to sugar and cotton plantations, as well as coal mines, turpentine farms, phosphate beds, brickyards, sawmills, and other outposts of entrepreneurial daring in the impoverished region."

Convict leasing, penal farms, and chain gangs were seen as natural arrangements against the background of slavery (Hindus 1980; Ayers 1984; Lichtenstein 1996; Colvin 1997) and effectively reinstituted slavery by a different means (Blackmon 2008; see Wacquant 2011). As with slavery, the operation was an economy for profit, made possible in this circumstance by the subtraction of prisoners' rights (Taylor 1993). Working conditions under these arrangements put prisoners at risk, often fatally.

Whereas to this point the article has focused on statements by reformers advocating the respective approaches, here a critic provides a systematic explanation of the form. George Washington Cable's essay, "The Convict Lease System in the Southern States" (1889), offers an overview of the system and its role in Southern criminal justice that was unparalleled. For Cable, a novelist who offered social commentary on issues of contemporary importance, the essay provided both an expression of public sentiment and, drawing from official statements, an inventory of arguments upon which the system was justified "through its own testimony" $(1889,130)$. Cable distinguished convict leasing ("the lease system"), practiced at that time in twelve Southern states, from other forms of penal industry. While operations varied in the extent to which a state was divested of prisoners' custody and care, the lease system generally lacked the security, discipline, and attention to rehabilitation that "harmonized" with the aims of imprisonment in other penal labor arrangements (123). Instead, Cable explained, the rationale of the lease system was simply this (126): "The system springs primarily from 
the idea that the possession of a convict's person is an opportunity for the State to make money; that the amount to be made is whatever can be wrung from him ... and that, without regard to moral or mortal consequences, the penitentiary whose annual report shows the largest cash balance paid into the State's treasury is the best penitentiary." In actors carrying out convict leasing, Cable saw less an interest to harm than an "unadmirable spirit of enterprise." And he interpreted the public's unconcerned acceptance of the practice as "little more than a listless oblivion, that may be reprehensible, but is not intentional, unless they are to be judged by the acts of their elected legislators" (127).

Whatever the motive, as Cable demonstrated in a state-by-state inventory, the consequences were dire. Leasing conducted in Tennessee's dispersed "branch prisons," for example, showed "rates of mortality startlingly large compared with the usual rates of well-ordered prisons." In Georgia and South Carolina, a "large majority" of prisoners had "been virtually condemned to be worked and misused to death" for "simple stealing, without breaking in or violence" (Cable 1889, 154). Death rates (and attempted escape rates) were high too in Texas and Alabama. But Cable saved the judgment of "the system at its worst" for Arkansas, Mississippi, and Louisiana (1889, 170; see Taylor 1993; Oshinsky 1996; Curtin 2000; see also McLennan 2011, 207, on Northern penal contract labor).

Contract prison labor had a heterogeneous relationship with formal life sentencing that intersected with race. In the late nineteenth century, few penal facilities in the South had the space or finances to hold large numbers of long-term prisoners. It is no surprise, then, that formal life sentencing increased as convict leasing gained traction after the Civil War. Yet this varied by state. In Georgia, by the late nineteenth century "the life sentence had become the most frequent single sentence" (Mancini 1996, 89, 96). Most were meted out to black prisoners, who were life-sentenced at a rate ten times that of whites (92) and assigned to the mines (Lichtenstein 1996, 116-18). The arrangement was different in Mississippi, where life imprisonment was a prison-based sentence meted out primarily to white offenders convicted of very serious crimes. As David Oshinsky put it: "The leasing act was designed for black, not white convicts" (1996, 14). In Mississippi, "white convicts received longer sentences than black because the courts of Mississippi did not normally punish whites for anything except the most heinous of crimes" (14). In other words, in Mississippi convict leasing was a punishment for blacks, regardless of the seriousness of the crime.

\section{Mercy and Forgetting}

In a striking passage, Cable "runs down the table of deaths" from a Tennessee branch prison: "Found dead. Killed. Drowned. Not given. Blank. Blank. Blank. Killed. Blank. Shot. Killed. Blank. Blank. Killed. Killed. Blank. Blank. Blank. Killed. Blank. Blank" (1889, 130-31). Finding a similar lack of explanation for deaths of leased prisoners in North Carolina, Cable laments that leased prisoners are not only worked to death, they are forgotten: "[T]he dark fact that eclipses everything else is that not a word is given to account for the deaths of 158 [approximately one-fifth] of these men, except that 11 were shot down in trying to escape" (144).

In this system, prisoners understood that release was a matter of luck rather than law, for no matter the length of the sentence, death could result. In that respect, prisoners relied on the mercy doled out by executive clemency: "Convicts yearned for luck-not 
justice-in their freedom songs because the standards for clemency were so capricious and corrupt" (Oshinsky 1996, 180). In some states, the clemency process relied on a link between prison administrators and the governor, by which administrators recommended prisoners for release (Gottschalk 2015); in this way, resource constraints could be managed in a sort of end run around formal sentencing laws. As Taylor states (1993, 223; see also Miller 2012, 208, on Florida): "[After] the emergence of a system of incentives that allowed superintendents to regulate the size and makeup of the convict population via the clemency powers of chief executives, the pressures created by the exacting penal code and by the independent judiciary were largely neutralized." Barring the occasional random interest a governor took in their fate (Taylor 1993), however, many convicts, a disproportionate number of them black, wasted away: "Every so often, a newspaper story would appear about a local Negro serving an interminable sentence at Parchman because no one cared enough to get him out. As time went by and these stories piled up, the press began to describe a class of 'forgotten men"' (Oshinsky 1996, 196).

\section{PERPETUAL PENAL CONFINEMENT IN CONTEXT}

The foregoing exposition presents five distinct ways of thinking about and practicing perpetual penal confinement. Detailed consideration of perpetual confinement's forms and functions in these classic schemes shows it to be a punishment produced in many ways, one that takes on different shapes and different uses depending on how it links to broader political projects, economic arrangements, and the institutions and practices of criminal justice apparatuses. More than a blunt tool for harsh punishment, it has been a product of different intentions, playing integral roles in the theoretical frameworks or practical workings of systems with different, even divergent, aims.

Why did these diverse thinkers, penal reformers, and prison administrators all find something critically necessary in perpetual confinement? It was not because the penal schemes prioritized imprisoning convicts for life. In furthering the principles of each system, rather, perpetual confinement provided something the general architecture of the penal law did not. For Cesare Beccaria, the penal code served to put the public on notice and deter crime through swift, certain, and proportionate sentences. While Beccaria (like Jeremy Bentham) recognized that perpetual public servitude conflicted with the principle of proportionality, he found it uniquely effective in certain circumstances as a visible and ongoing deterrent. For Benjamin Rush, the prison served to train fringe members of society to become citizens. While release from prison upon reform was the aim of the retreat, leaving sentence lengths unknown was expected to invoke fear that would promote internal transformation. Frederick Wines and other Progressive reformers also envisioned the prison as an opportunity for criminals to work toward rehabilitation and reenter society. Although antithetical to the treatment model's principal objective, perpetual confinement was critical to the program as a backstop for cases in which rehabilitation failed. Daniel Raymond believed the prison was only effective at rehabilitation in short terms. For Raymond and other dual track proponents, the separate track scheme avoided contaminating rehabilitation-oriented penal facilities by quarantining prisoners identified as unlikely to quickly reform. Finally, as George Washington Cable observed, the convict lease system in effect overwrote the penal 
law by exploiting prisoners under conditions that worked them to death, regardless of the sentence imposed. In each of these diverse systems, perpetual confinement furthered the principles of the overall enterprise by accomplishing a task that standard sentencing options were not well equipped for or that the penal law was not generally authorized to do. One could say that perpetual confinement, while not necessarily a rare occurrence, was nevertheless an exceptional punishment as it served a unique purpose, which differed depending on the scheme.

Perpetual confinement's value derived in part from its temporal aspect. The prison traditionally has operated by removing from individuals "the time left to live" (Foucault 2015,72 ). In the conventional temporality of sentencing and the prison, time is the measure. ${ }^{5}$ Time is a measure, moreover, counted on to pass with an eye toward release. The notion of imprisonment as a sentence of duration with a finite end point is deeply engrained in modern Western punishment. With perpetual confinement, however, devices such as calendars and clocks no longer chart the days to freedom. For a diverse array of reformers, policy makers, and prison administrators (and subcontractors, in the case of the lease system), perpetual confinement was useful in part precisely because it provided a different sense of time. Beccaria valued the perpetual sentence because it broke time into an endlessly repeating present-he perceived the punishment's worth in terms of repetition, not duration. Rush and Wines, despite the differences in their schemes, both found duration an imprecise and often mistaken way of gauging the degree of punishment and a prisoner's readiness for release (Wines likened it to the impossibility of catching sunbeams). Instead they preferred open-ended sentences that rewarded achievement, evinced through psychological or physical labor. With convict leasing, the duration of the punishment imposed by sentencing law was supplanted in practice as a measure by labor hours, productivity, and, ultimately, day-to-day survival. Daniel Raymond, who saw the passing of time as an impediment to rehabilitation and as fuel for prisonization, discarded time altogether when it came to the perpetual workhouse for serious or repeat offenders.

Reformers also looked to perpetual confinement to manipulate the lived experience of imprisonment. One way in which the timelessness of perpetual confinement affects prisoners is captured in the notion of hope, a present anticipation of a better future. Recent prisoner autobiographical writing (the works collected in Hartman 2013, for example) and social science research (see Jewkes 2005; Johnson and McGunigall-Smith 2008; O'Donnell 2014; Leigey 2015; Lempert 2016; Vannier 2016; Herbert 2018) acutely express the currents of hope and hopelessness involved in life sentences ending in death. The historical modes demonstrate how, by eliminating a calculable or identifiable end point, some reformers sought to affect how prisoners viewed their prospects for release and thereby motivate prisoners' behavior. For Rush, who anticipated that prisoners would achieve redemption and reform in isolation and darkness, persuading prisoners to abandon all reasonable possibility of release was a part of the process. For Wines, who conceived of hope as something generated in day-to-day work toward rehabilitation and earned in pursuit of the "chance" to earn release,

5. As Evgeny Pashukanis observes, "Deprivation of freedom, for a period stipulated in the court sentence, is the specific form in which modern, that is to say bourgeois-capitalist, criminal law embodies the principle of equivalent recompense" (1978, 180-81). 
however, denying a prisoner a right to review for release outright would have extinguished hope, whereas the possibility of losing the "chance" served as an incentive for reform. As with the features of perpetual confinement more generally, reformers' ideas about the nature of hope were linked to assumptions about prisoners, the functions of the prison, and the aims of the penal system.

Perpetual confinement has a rich history in US penal thought and practice. In significant part because of its temporal character, it has been valuable to schemes with a diverse range of political and penal goals. Yet it bears emphasis that in these classic paradigms perpetual confinement played important yet bounded roles, complementing overarching penal aims while nevertheless remaining an approach for the special case or alternative track.

\section{A CONTEMPORARY MODE OF PERPETUAL CONFINEMENT}

The primary purpose of this article has been to establish perpetual confinement as a category with historical import and identify it as a way of understanding systems of punishment. I have suggested that we see perpetual confinement as, more than a severe punishment, a type of punishment that is produced in many ways and that takes on different forms and serves different functions depending upon the context. The preceding sections discussed how, across political and penal projects with different and even divergent aims, perpetual confinement buttressed the standard criminal law by providing a feature that other sentencing options did not. This section, in closing, comments on how the study of historical modes of perpetual confinement can expand understanding of punishment in the present, specifically by looking to the context of the contemporary United States.

Scholars today recognize life without parole (LWOP) as a cardinal feature of US punishment (Van Zyl Smit 2002; Ogletree and Sarat 2012; Gottschalk 2015; Steiker and Steiker 2016; Tonry 2016). This is not only because the use of LWOP, an emergent form of perpetual confinement, has quintupled in recent decades. More, scholars assert, LWOP captures the zeitgeist of contemporary US punishment (Dolovich 2012; Simon 2012, 2014; Dilts 2015; Girling 2016; Dichter 2017). Jonathan Simon (2012, 2014) shows that LWOP epitomizes a punitive and zero-risk way of thinking about and carrying out punishment (what he dubs "total incapacitation") that undergirds mass incarceration. In Simon's words, LWOP “defines the logic of contemporary penality ... in its embrace of a totalizing promise of prison incapacitation extended to the very limits of life, and unmediated by any further consideration of the prisoner as a distinct human being" (2012, 282). Speaking not only of physical incapacitation but of social control, Sharon Dolovich finds LWOP exemplary of "many penal strategies in place to maintain the boundary between inmates and the broader society," including deficient prison conditions, constrained parole possibilities, and collateral consequences of imprisonment that last a lifetime $(2012,99)$. As Dolovich puts it, LWOP reflects the "central motivating aim" of a US penal system dedicated to "wholesale banishment" (96). Thomas Dichter likewise argues that "LWOP embodies the logic of incorrigibility and banishment that infuses the carceral state at many levels: from the imposition of long sentences, to mass deportation, to exclusions of the formerly incarcerated from civic life upon release" $(2017,20)$. Dichter recognizes LWOP as the latest in a legacy of race-driven 
policies and practices in the United States supporting the exclusion of an "incorrigible" class of offenders.

In these theories, as with the historical modes, perpetual confinement (here, LWOP) is recognized to take shape and operate according to principles and assumptions that underlie a broader political project or criminal justice strategy (here, the cruel and exclusionary ethos of contemporary American criminal justice). Yet the historical forms and functions discussed in this article also draw attention to a significant difference. I have argued that perpetual confinement was valuable in classic penal paradigms because it possessed a distinctive temporal quality and that it was used when that quality made a difference. Even in the deliberate and sweepingly broad exclusionary penal model set forth by Daniel Raymond, the place of perpetual confinement was circumscribed-a clear distinction existed between ordinary criminals who would receive corporal punishment or serve short prison terms and those extraordinary offenders whom the state could, on a separate track, imprison until death. In the sentencing frameworks that prevail in most US states today, by contrast, perpetual confinement, with LWOP as its bellwether, is not reserved for the special case or separate track. Most US jurisdictions have adopted fixed sentencing schemes (including determinate sentencing, mandatory minimum sentencing, and truth-in-sentencing provisions), imposing prison sentences for set terms of years that are often long and often mandatory (Tonry 2016). ${ }^{6}$ While LWOP does, as scholars have recognized, instantiate the logic of such penal schemes, LWOP does not serve a unique role. Rather, it is one among other fixed long-term sentences.

The US Supreme Court decision in Harmelin v. Michigan (501 U.S. 957 (1991)) provides an illustration of LWOP's fit in contemporary American penal systems. Harmelin involved a state-imposed mandatory LWOP sentence for a first-time cocaine possession offense. Long fixed prison terms were common punishments for drug trafficking and possession in Michigan and many other jurisdictions at the time. Throughout the Harmelin litigation, stifling drug trafficking was considered so important a policy objective that imposing a punishment as severe as LWOP for serious drug offenses was hardly questioned. Rather than attempt to minimize the severity of an LWOP sentence, Michigan and supporting amici curiae embraced LWOP as representative of a widespread practice of imposing long and mandatory fixed sentences for drug crimes (see Brief of the United States, Harmelin v. Michigan, No. 89-7272). Upholding Harmelin's sentence, the Court followed the state's line of argument, likening LWOP to a long fixed term of forty or fifty years or more and determining that LWOP could not be meaningfully distinguished from other long mandatory sentences (501 U.S. at 996). In the words of one amicus brief, if LWOP violates the Eighth Amendment, "[d]oes that mean any term of years greater than the defendant's life expectancy [does]?" (Brief of Washington Legal Foundation, Harmelin v. Michigan, No. 897272, at 16-17). A plurality of the Court concluded that LWOP, like other noncapital sentences, would be unconstitutional only in rare cases of "gross disproportionality" (Harmelin, 501 U.S. at 1001, plurality opinion of Kennedy, J.). Beyond signaling that

6. While some fixed sentencing schemes were initially adopted with the aim of limiting the discretion of judicial and administrative actors, in order to even out sentence lengths and reduce arbitrariness in sentencing and release, over time the focus turned to ensuring that prisoners serve out sentences in full (or nearly so) and the average length of sentences increased (Tonry 2016; see Seeds 2018). 
LWOP is constitutionally valid punishment for a wide range of crimes, Harmelin illustrates LWOP's fit in many state schemes and in a paradigm that favors long, determinate sentences. LWOP is a punishment that can be used routinely for a variety of offenses in much the same way as long fixed (and sometimes mandatory) terms of years. As Marie Gottschalk notes, "LWOP and other life sentences are a widely used but unremarkable part of the sentencing toolkit in the United States" (Gottschalk 2012, 233; see Zimring and Johnson 2012, 747). Perpetual confinement here is not an exceptional punishment, but a particularly strong form of the standard approach.

I would suggest that as LWOP stabilizes as a standard penal practice, it may have the latent effect of crystalizing a new familiarity with perpetual penal confinement. We see some indication of this in the fact that litigants, policy analysts, and scholars now classify punishments that are not formally life without parole, but that nevertheless achieve the result of imprisonment for the rest of natural life, as "de facto life without parole." LWOP offers a ready way of understanding less visible forms of perpetual confinement, such as parole practices that consistently deny release based on the circumstances of the crime (Ghandnoosh 2017; Reitz 2018) and sentencing practices that impose very long terms with the intention of incarcerating until death (Hamilton 2016). ${ }^{7}$ By identifying with LWOP, these punishments relate to a broader practice of perpetual confinement.

Scholars have well recognized that LWOP is a cruel, exclusionary, and racialized feature of contemporary US punishment. The past theories and practices discussed in this article show how perpetual confinement has long been so. Placed in historical relief, what makes the contemporary context remarkable is that there is little distinctive about perpetual confinement. Beyond reflecting a penality bent on cruelty and exclusion, LWOP is symptomatic of a system in which incarcerating until death is a standard sentence and a routine practice. With LWOP, perpetual penal confinement has lost its aura. ${ }^{8}$

\section{REFERENCES}

Abend, Gabriel. The Moral Background. Princeton: Princeton University Press, 2014.

Allen, Frederick. The Decline of the Rehabilitative Ideal: Penal Policy and Social Purpose. New Haven, CT: Yale University Press, 1981.

Allen, Stephen, Samuel Hopkins, and George Tibbits. Report. Journal of the State of New York. Albany, NY: New York Legislature, 1825.

7. One might also include death sentences that do not result in execution. That LWOP and its functional equivalents are not so meaningfully different from death sentences has long been truer than Eighth Amendment jurisprudence allows (Girling 2016; see Dilts 2015). This is especially so today, as fewer executions are carried out and death-sentenced prisoners live out their lives on death row (O'Donnell 2014, 148).

8. The processes of this development remain to be researched and better understood; so do the societal implications of treating imprisonment until death as noncontroversial. Put another way, the social implications of penal laws and practices "organiz[ed] ... with an expectation of death" (Liebling 2017, 28) remain to be uncovered. Discussing whole life sentences (a functional equivalent of life without parole sentences), as well as prison deaths resulting from suicides and murders, in England and Wales, Alison Liebling uses the phrase "organizing prisons with an expectation of death" (28 (emphasis added)). "[T]he ending of life in custody," Liebling argues, "should be controversial" (20). Although Liebling is addressing prison administration in England and Wales, the phrase resonates with the point I make about penal laws and practices in the contemporary United States: in many jurisdictions, imprisonment until death has become a barely questioned and standard outcome. 
Ayers, Edward. Vengeance and Justice: Crime and Punishment in the 19th-Century American South. New York: Oxford University Press, 1984.

Barkow, Rachel E. "Life Without Parole and the Hope for Real Sentencing Reform." In Life Without Parole: America's New Death Penalty?, edited by Charles Ogletree and Austin Sarat, 190-226. New York: New York University Press, 2012.

Barnes, Harry Elmer. Evolution of Penology in Pennsylvania. Montclair, NJ: Patterson Smith, [1927] 1968.

Barnes, Harry Elmer, and Negley Teeters. New Horizons in Criminology. New York: Prentice Hall, 1952.

Beaumont, Gustave de, and Alexis de Toqueville. On the Penitentiary System in the United States. Translated by Francis Lieber. Philadelphia: Carey, Lea \& Blanchard, 1833.

Beccaria, Cesare. On Crimes and Punishments, and Other Writings. Translated by Henry Paolucci. Indianapolis, IN: Bobbs-Merrill, [1764] 1963.

. "On Crimes and Punishments." In On Crimes and Punishments and Other Writings, edited by Aaron Thomas. Toronto: University of Toronto Press, [1764] 2008.

. "Opinion of the Undersigned Members of the Committee Charged with the Reform of the Criminal System in Austrian Lombardy for Matters Pertaining to Capital Punishment." In On Crimes and Punishments and Other Writings, edited by Aaron Thomas. Toronto: University of Toronto Press, [1792] 2008.

Becker, Howard P. "Constructive Typology in the Social Sciences." American Sociological Review 5, no. 1 (1940): 40-55.

Bedau, Hugo A. "Bentham's Utilitarian Critique of the Death Penalty." Journal of Criminal Law and Criminology 74, no. 3 (1983): 1033-66.

. "Imprisonment vs. Death: Does Avoiding Schwarzschild's Paradox Lead to Sheleff's Dilemma?" Albany Law Review 54, no. 3-4 (1989): 481-95.

Bell, Kristen. "A Stone of Hope: Legal and Empirical Analysis of California Juvenile Lifer Parole Decisions" (October 4, 2018). Forthcoming in Harvard Civil Rights-Civil Liberties Law Review. Available at SSRN: https://ssrn.com/abstract=3228681 or http://dx.doi.org/10.2139/ssrn.3228681

Bentham, Jeremy. "Principles of Morals and Legislation." In The Works of Jeremy Bentham, edited by John Bowring, vol. I. Edinburgh: William Tait, 1843.

Bessler, John D. "Revisiting Beccaria's Vision: The Enlightenment, the Death Penalty, and the Abolition." Northwestern Journal of Law and Social Policy 4, no. 2 (2009): 195-328.

Bierne, Piers. Inventing Criminology: Essays on the Rise of 'Homo Criminalis'. Albany, NY: State University of New York Press, 1993.

Blackmon, Douglas A. Slavery by Another Name: The Re-Enslavement of Black Americans from the Civil War to World War II. New York: Random House, 2008.

Bright, Charles. The Powers that Punish: Prison and Politics in the Era of the 'Big House', 1920-1955. Ann Arbor: University of Michigan Press, 1996.

Cable, George Washington. The Silent South, Together with The Freedman's Case in Equity and The Convict Lease System in the Southern States. New York: Charles Scribner's Sons, 1889.

Clemmer, Donald. The Prison Community. New York: Holt, Rinehart, Winston, 1940.

Colvin, Mark. Penitentiaries, Reformatories, and Chain Gangs: Social Theory and the History of Punishment in 19th-Century America. New York: St. Martin's Press, 1997.

Cullen, Francis T., and Karen E. Gilbert. Reaffirming Rehabilitation. London: Routledge, 2013.

Curtin, Mary Ellen. Black Prisoners and Their World, Alabama, 1865-1900. New Brunswick, NJ: Rutgers University Press, 2000.

Dayan, Colin. The Law Is a White Dog: How Legal Rituals Make and Unmake Persons. Princeton, NJ: Princeton University Press, 2011.

Dichter, Thomas Alan. "Worst of the Worst: Rehabilitationist Roots of Life Without Parole." Law, Culture and the Humanities (2017). doi: 10.1177/1743872117733190.

Dilts, Andrew. "Death Penalty 'Abolition' in Neoliberal Times". In Death and Other Penalties: Philosophy in a Time of Mass Incarceration, edited by Geoffrey Adelsberg, Lisa Geunther, and Scott Zeman, 106-29. New York: Fordham University Press, 2015.

Dolovich, Sharon. "Creating the Permanent Prisoner." In Life Without Parole: America's New Death Penalty?, edited by Charles Ogletree and Austin Sarat, 96-137. New York: New York University Press, 2012. 
Fitzroy, Herbert William Keith. "The Punishment of Crime in Provincial Pennsylvania." Pennsylvania Magazine of History and Biography 60, no. 3 (1936): 242-69.

Foucault, Michel. Discipline and Punish: The Birth of the Prison. Translated by Alan Sheridan. New York: Vintage, 1977.

—. "About the Concept of the 'Dangerous Individual' in 19th-Century Legal Psychiatry." International Journal of Law and Psychiatry 1 (1978): 1-18.

- The Punitive Society: Lectures at the Collège de France, 1972-1973. Translated by Graham Burchell. New York: Palgrave MacMillan, [1972-1973] 2015.

Garland, David. Punishment and Welfare: A History of Penal Strategies. London: Ashgate, 1985.

—. "Frameworks of Inquiry in the Sociology of Punishment." British Journal of Sociology 41, no. 1 (1990): 1-15.

- The Culture of Control: Crime and Social Order in Contemporary Society. Chicago: University of Chicago Press, 2001.

. "Of Crimes and Criminals: The Development of Criminology in Britain." The Oxford Handbook of Criminology 3 (2002): 7-50.

- Peculiar Institution: America's Death Penalty in an Age of Abolition. Cambridge, MA: The Belknap Press, 2010.

. "Modes of Capital Punishment: The Death Penalty in Perspective." In America's Death Penalty: Between Past and Present, edited by David Garland, Randall McGowen, and Michael Meranze, 30-71. New York: NYU Press, 2011.

Ghandnoosh, Nazgol. Delaying a Second Chance: The Declining Prospects for Parole on Life Sentences. Washington, DC: The Sentencing Project, 2017.

Girling, Evi. "Sites of Crossing and Death in Punishment: The Parallel Trade-Offs and Equivalencies of the Death Penalty and Life Without Parole in the US." Howard Journal of Crime and Justice 55, no. 3 (2016): 345-61.

Gottschalk, Marie. "No Way Out? Life Sentences and the Politics of Penal Reform." In Life Without Parole: America's New Death Penalty?, edited by Charles Ogletree and Austin Sarat, 227-81. New York: New York University Press, 2012.

- Caught: The Prison State and the Lockdown of American Politics. Princeton, NJ: Princeton University Press, 2015.

Hacker, Frederick, and Marcel Frym. "The Sexual Psychopath Act in Practice: A Critical Discussion." California Law Review 43, no. 5 (1955): 766-80.

Hamilton, Melissa. "Extreme Prison Sentences: Legal and Normative Consequences." Cardozo Law Review 38, no. 1 (2016): 59-120.

Harcourt, Bernard. The Illusion of Free Markets: Punishment and the Myth of Natural Order. Cambridge, MA: Harvard University Press, 2011.

Hartman, Kenneth E., ed. Too Cruel, Not Unusual Enough. Lancaster, CA: The Other Death Penalty Project, 2013.

Henry, Jessica S., Christopher Salvatore, and Bai-Eyse Pugh. "Virtual Life Sentences: An Exploratory Study." The Prison Journal 98, no. 3 (2018): 294-313.

Herbert, Steve. Too Easy to Keep: Life-Sentenced Prisoners and the Future of Mass Incarceration. Oakland, CA: University of California Press, 2018.

Hindus, Michael S. Prison and Plantation: Crime, Justice, and Authority in Massachusetts and South Carolina, 1767-1878. Chapel Hill, NC: University of North Carolina Press, 1980.

Hirsch, Adam J. The Rise of the Penitentiary: Prisons and Punishment in Early America. New Haven: Yale University Press, 1992.

Howard, John. An Account of the Principal Lazarettos in Europe. Warrington: Eyres, 1789.

Janus, Eric, and Robert Prentky. "Sexual Predator Laws: A Two-Decade Retrospective." Federal Sentencing Reporter 21, no. 2 (2008): 90-97.

Jenkins, Philip. Moral Panic: Changing Concepts of the Child Molester in Modern America. New Haven: Yale University Press, 2004.

Jewkes, Yvonne. "Loss, Liminality and the Life Sentence." In The Effects of Imprisonment, edited by Alison Liebling and Shadd Maruna, 366-88. New York: Willan Publishing, 2005. 
Johnson, Robert, and Sandra McGunigall-Smith. "Life Without Parole: America's Other Death Penalty: Notes on Life under Sentence of Death by Incarceration." The Prison Journal 88, no. 2 (2008): 328-46.

Kazemian, Lila, and Jeremy Travis. "Imperative for Inclusion of Long Termers and Lifers in Research and Policy." Criminology and Public Policy 14, no. 2 (2015): 355-95.

Kramer, Ronald C. "From 'Habitual Offenders' to 'Career Criminals': The Historical Construction and Development of Criminal Categories." Law and Human Behavior 6, no. 3-4 (1982): 273-93.

Langbein, John H. "The Historical Origins of the Sanction of Imprisonment for Serious Crime." Journal of Legal Studies 5, no. 1 (1976): 35-60.

Leigey, Margaret. The Forgotten Men: Serving a Life Without Parole Sentence. New Brunswick, NJ: Rutgers University Press, 2015.

Lempert, Lora Bex. Women Doing Life: Gender, Punishment and the Struggle for Identity. New York: New York University Press, 2016.

Leon, Chrysanthi. Sex Fiends, Perverts, and Pedophiles: Understanding Sex Crime Policy in America. New York: NYU Press, 2011.

Lewis, W. D. From Newgate to Dannemora: The Rise of the Penitentiary in New York, 1746-1848. Ithaca, NY: Cornell University Press, 1965.

Lichtenstein, Alex. Twice the Work of Free Labor: The Political Economy of Convict Labor in the New South. New York: Verso, 1996.

Liebling, Alison. "The Meaning of Ending Life in Prison." Journal of Correctional Health Care 23, no. 1 (2017): 20-31.

Lombroso, Cesare. Criminal Man. Translated by Mary Gibson and Nicole Hahn Rafter. Durham, NC: Duke University Press, [1896] 2006.

Lynch, Mona. "Pedophiles and Cyber-predators as Contaminating Forces: The Language of Disgust, Pollution, and Boundary Invasions in Federal Debates on Sex Offender Legislation." Law and Social Inquiry 27, no. 3 (2002): 529-57.

- Sunbelt Justice: Arizona and the Transformation of American Punishment. Palo Alto, CA: Stanford Law Books, 2010.

Mancini, Matthew. One Dies, Get Another: Convict Leasing in the American South, 1866-1928. Columbia, SC: University of South Carolina Press, 1996.

McCuaig, J. A. Royce. "Modern Tendencies in Habitual Criminal Legislation." Cornell Law Quarterly 15, no. 1 (1929): 62-83.

McLennan, Rebecca. The Crisis of Imprisonment. New York: Cambridge University Press, 2008.

—. "The Convict's Two Lives: Civil and Natural Death in the American Prison." In America's Death Penalty: Between Past and Present, edited by David Garland, Randall McGowen, and Michael Meranze, 191-220. New York: NYU Press, 2011.

Meranze, Michael. "Introduction." In Benjamin Rush, Essays: Literary, Moral and Philosophical, edited by Michael Meranze. Schenectady, NY: Union College Press, 1988.

- Laboratories of Virtue: Punishment, Revolution, and Authority in Philadelphia, 1760-1835. Chapel Hill, NC: University of North Carolina Press, 1996.

Miller, Vivien. Hard Labor and Hard Time: Florida's "Sunshine Prison" and Chain Gangs. Gainesville, FL: University Press of Florida, 2012.

Morris, Norval. The Habitual Criminal. Cambridge: Longmans Green \& Co., 1951.

—. "Introduction." McGill Law Journal 13, no. 4 (1967): 534-52.

Nellis, Ashley. Still Life: America's Increasing Use of Life and Long-Term Sentences. Washington, DC: The Sentencing Project, 2017.

Newman, Graeme, and Pietro Marongiu. Introduction to Of Crimes and Punishments, by Cesare Beccaria. Somerset, NJ: Transaction Publishers, 2009.

O'Donnell, Ian. Prisoners, Solitude, and Time. Oxford: Oxford University Press, 2014.

Ogletree, Charles J., and Austin Sarat. Life Without Parole: America's New Death Penalty? New York: New York University Press, 2012.

Oshinsky, David. Worse Than Slavery: Parchman Farm and the Jim Crow Justice System. New York: Free Press, 1996. 
Pashukanis, Evgeny. Law and Marxism: Towards a Critique of the Fundamental Juridical Concepts. Worcester, UK: Billing and Sons, Ltd., 1978.

Pifferi, Michele. Reinventing Punishment: A Comparative History of Criminology and Penology in the Nineteenth and Twentieth Centuries. Oxford: Oxford University Press, 2016.

Radzinowicz, Leon, and Roger Hood. "Incapacitating the Habitual Criminal: The English Experience." Michigan Law Review 78, no. 8 (1980): 1305-89.

Raymond, Daniel. Report on the Penitentiary System in the United States, Appendix. New York: Mahlan Day, 1822.

Reitz, Kevin R. "The 'Traditional' Indeterminate Sentencing Model." In The Oxford Handbook of Sentencing and Corrections, edited by Joan Petersilia and Kevin R. Reitz, 270-98. New York: Oxford University Press, 2012.

—. "American Exceptionalism in Crime and Punishment: Broadly Defined." In American Exceptionalism in Crime and Punishment, edited by Kevin R. Reitz, 53-102. New York: Oxford University Press, 2018.

Rothman, David J. Discovery of the Asylum. Boston: Little Brown, 1971.

—. "Perfecting the Prison." In The Oxford History of the Prison, edited by Norval Morris and David J. Rothman, 100-16. New York: Oxford University Press, 1995.

Rubin, Ashley T. "A Neo-Institutional Account of Prison Diffusion." Law and Society Review 49, no. 2 (2015): 365-400.

. "Penal Change as Penal Layering." Punishment and Society 18, no. 4 (2016): 420-41.

Rusche, Georg, and Otto Kirchheimer. Punishment and Social Structure. New Brunswick, NJ: Transaction Publishers, [1939] 2003.

Rush, Benjamin. An Enquiry into the Effects of Public Punishments upon Criminals and upon Society. Philadelphia: Society for Social Inquiry, 1787.

- Considerations on the Injustice and Impolicy of Punishment Murder by Death. Philadelphia: Matthew Carey, 1792.

Schmitt, Glenn R., and Hyun J. Konfrst. Life Sentences in the Federal System. Washington, DC: United States Sentencing Commission, 2015.

Schoenfeld, Heather. "The Delayed Emergence of Penal Modernism in Florida." Punishment and Society 16, no. 3 (2014): 258-84.

Seeds, Christopher. "Bifurcation Nation: American Penal Policy in Late Mass Incarceration." Punishment and Society 19, no. 5 (2017): 590-610.

. "Disaggregating LWOP: Life Without Parole, Capital Punishment, and Mass Incarceration in Florida, 1972-1995." Law and Society Review 52, no. 1 (2018): 172-205.

Sellin, Thorsten. Slavery and the Penal System. New York: Elsevier, 1976.

—. "Beccaria's Substitute for the Death Penalty." In Criminology in Perspective: Essays in Honor of Israel Drapkin, edited by Simha Landau and Leslie Sebba, 3-9. Lexington, MA: Lexington Books, 1977.

Sheleff, Leon. Ultimate Penalties: Capital Punishment, Life Imprisonment, Physical Torture. Columbus, OH: Ohio State University Press, 1987.

Simon, Jonathan. Governing Through Crime: How the War on Crime Transformed American Democracy and Created a Culture of Fear. New York: Oxford University Press, 2007.

. "Dignity and Risk: The Long Road from Graham v. Florida to Abolition of Life Without Parole." In Life Without Parole: America's New Death Penalty?, edited by Charles Ogletree and Austin Sarat, 282-310. New York: New York University Press, 2012.

- Mass Incarceration on Trial: A Remarkable Court Decision and the Future of Prisons in America. New York: The New Press, 2014.

Skinner, Quentin. "Meaning and Understanding in the History of Ideas." History and Theory 8, no. 1 (1969): 3-53.

Smith, Philip. Punishment and Culture. Chicago: University of Chicago Press, 2008.

Steiker, Carol, and Jordan Steiker. Courting Death: The Supreme Court and Capital Punishment. Cambridge, MA: The Belknap Press, 2016.

Sutherland, Edwin. "The Sexual Psychopath Laws." Journal of Criminal Law, Criminology and Police Science 40, no. 5 (1949): 543-54. 
Swanson, Alan. "Sexual Psychopath Statutes: Summary and Analysis." Journal of Criminal Law, Criminology and Police Science 51 (1960): 215-35.

Tallack, William. Penological and Preventive Principles. London: Wertheimer, Lea \& Co., 1889.

—. "Long Imprisonments." The Times (London, England), September 2, 1896, 9.

Tappan, Paul. "Habitual Offender Laws in the United States." Federal Probation 13 (1949): 28.

Taylor, William Banks. Brokered Justice: Race, Politics, and Mississippi Prisons, 1798-1992. Columbus, OH: Ohio State University Press, 1993.

Teeters, Negley. The Cradle of the Penitentiary: The Walnut Street Jail, 1773-1835. Philadelphia: Pennsylvania Prison Society, 1955.

Timashefe, N. S. "The Treatment of Persistent Offenders outside of the United States." Journal of Criminal Law and Criminology 30, no. 4 (1939): 455-69.

Tonry, Michael. Sentencing Fragments: Penal Reform in America, 1975-2005. New York: Oxford University Press, 2016.

Vannier, Marion. "Women Serving Life without the Possibility of Parole." The Howard Journal of Crime and Justice 55, no. 3 (2016): 328-44.

Van Zyl Smit, Dirk. Taking Life Imprisonment Seriously: In National and International Law. Norwell, MA: Kluwer Law International, 2002.

Van Zyl Smit, Dirk, and Catherine Appleton. Life Imprisonment and Human Rights. Oñati International Series in Law and Society. Oxford and Portland, OR: Hart Publishing, 2016. . Life Imprisonment: A Global Human Rights Analysis. Cambridge, MA: Harvard University Press, 2019.

Virginia Law Review. “Recidivism and Virginia's ‘Come Back’ Law.” Virginia Law Review 48 (1962): 597-641.

Wacquant, Loic. "From Slavery to Mass Incarceration: Rethinking the 'Race Question' in the US." In Why Punish? How Much?: A Reader on Punishment, edited by Michael Tonry, 387-402. New York: Oxford University Press, 2011.

Wines, Enoch. Transactions of the National Congress on Penitentiary and Reformatory Discipline. Albany, NY: The Argus Company, 1870.

Wines, Enoch, and Theodore Dwight. Report on the Prisons and Reformatories of the United States and Canada. Albany, NY: Van Benthuysen \& Sons, 1867.

Wines, Frederick. Monograph on Sentences for Crime. Springfield, IL: H.W. Rocker, 1885.

- Punishment and Reformation: An Historical Sketch of the Rise of the Penitentiary. London: Swan Sonnenschein, 1895.

The New Criminology. New York: Kempster Print Co., 1904.

Young, David B. "Beccaria: Utilitarian or Retributivist." Journal of Criminal Justice 11, no. 4 (1983): 317-26.

Zimring, Franklin E., and David T. Johnson. "The Dark at the Top of the Stairs: Four Destructive Influences of Capital Punishment on American Criminal Justice." In The Oxford Handbook of Sentencing and Corrections, edited by Joan Petersilia and Kevin Reitz, 737-52. New York: Oxford University Press, 2012.

\section{CASES CITED}

Harmelin v. Michigan, 501 U.S. 957 (1991). 